\title{
ANALISIS USAHATANI JAMUR TIRAM PUTIH (Pleurotusostreatus) \\ DI KELURAHAN SIMPANG BARU KECAMATAN TAMPAN \\ KOTA PEKANBARU
}

\author{
Retno Dewi Shintia dan Amalia \\ Fakultas Pertanian Universitas Lancang Kuning \\ Jl.Yos Sudarso Km.8 Rumbai Pekanbaru \\ Retnodewi@yahoo.com, Amaliamasjkur@yahoo.co.id
}

\begin{abstract}
This study aims to (1) analyze costs and farm income oyster mushroom in the village of Simpang Baru subdistrict Tampan Pekanbaru, (2) analyzing the viability of farming oyster mushroom in the village of Simpang New District of Pekanbaru, (3) Analyze Break Even Point (BEP ) white oyster mushroom business in the village new intersections Handsome District of the city of Pekanbaru.

The sampling technique using census method. The results showed that during the production process ( 4 months) from 5000 baglog oyster mushrooms can produce immediate of $1200 \mathrm{~kg}$, with a selling price at farmer level Rp. 30,000 / Kg. Total gross revenue for Rp.36.000.000, total production cost of $\mathrm{Rp}$. 17,604,912. and net income of Rp. 18,395,088. BEP value sales of Rp. 5,668,708 and BEP unit amounted to $189.88 \mathrm{Kg}$. BCR value of 0.24 so that it can be concluded that the oyster mushroom farm in the village of Simpang Baru Subdistrict Tampan Pekanbaru City deserves to be continued
\end{abstract}

Keywords: white oyster mushroom, BEP, BCR

\begin{abstract}
Abstrak
Penelitian ini bertujuan untuk (1) menganalisan biaya dan pendapatan usahatani jamur tiram putih di Kelurahan Simpang Baru Kecamatan Tampan Kota Pekanbaru, (2)menganalisis kelayakan usahatani jamur tiram putih di Kelurahan Simpang Baru Kecamatan Kota Pekanbaru, (3) Menganalisis Break Even Point (BEP) usaha jamur tiram putih di kelurahan Simpang brau Kecamatan Tampan Kota Pekanbaru.

Teknik pengambilan sampel dilakukan dengan metode sensus. Hasil penelitian menunjukkan bahwa sealama satu kali proses produksi (4 bulan) dari 5.000 baglog dapat menghasilkan produk jamur tiram segara sebanyak $1200 \mathrm{Kg}$, dengan harga jual di tingkat petani sebesar Rp. 30.000/Kg. Jumlah pendapatan kotor sebesar Rp.36.000.000, Total biaya produksi sebesar Rp. 17.604.912. dan Pendapatan bersih sebesar Rp. 18.395.088. Nilai BEP penjualan sebesar Rp. 5.668.708 dan BEP unit sebesar 189.88 Kg. Nilai BCR sebesar 0,24 sehingga
\end{abstract}


dapat disimpulkan bahwa usahatani jamur tiram putih di kelurahan Simpang Baru Kecamatan Tampan Kota Pekanbaru layak untuk dilanjutkan

Kata Kunci: Jamur tiram putih, BEP, BCR

\section{BAB I PENDAHULUAN 1.1 Latar Belakang}

Indonesia dikenal sebagai negara agraris yang berarti negara yangmengandalkan sektor pertanian baik sebagai sumber mata pencaharian maupun sebagai penopang pembangunan. Pertanian merupakan salah satusektor yang sangat dominan dalam pendapatan masyarakat di Indonesia karena mayoritas penduduk Indonesiabekerja sebagai petani. Namun produktivitas pertanian masih jauh dari harapan.Salah satu faktor penyebab kurangnya produktivitas pertanian adalah sumber daya manusia yang masih rendah dalam mengolah lahan pertanian dan hasilnya.Mayoritas petani di Indonesia masih menggunakan sistem manual dalam pengolahan lahan pertanian (Gadang, 2011).

Pembangunan pertanian tanaman pangan bertujuan untuk meningkatkan pendapatan dan kesejahteraan petani khususnya, serta masyarakat pada umumnya, melalui peningkatan produksi pangan.Salah satu komoditi pertanian tanaman pangan yang mempunyai peluang cukup baik, dan produksi yang cukup besar adalah komoditi tanaman holtikultura.Pengembangan dan peningkatan agribisnis selaras dengan tujuan pembangunan pertanian di Indonesia yaitu untuk meningkatkan pendapatan dan taraf hidup petani secara lebih merata.

Pengembangan komoditi tanaman hortikultura berbasis pada komoditas unggulan yang mengacu pada pangsa pasar, keunggulan kompetitif, nilai ekonomi, sebaran wilayah produksi dan kesesuaian agroekosistem.Komoditi unggulan nasional holtikultura antara lain pisang, mangga, jeruk, durian, kentang, cabe merah, bawang merah, anggrek, kacang-kacangan, dan rimbang.Namun pada daerah spesifik juga mencakup komoditas unggulan daerah seperti salak, markisa, anggur, rambutan dan termasuk juga jamur tiram.

Kebiasaan mengkonsumsi jamur memang sudah lama dijalankan, lebih dari 1.000 tahun yang lalu. Karena manfaat dan nilai gizi yang terkandung di dalam jamur, bahkan kininegara-negara maju telah mewajibkan masyarakatnya untuk memasukkan jamur di dalam daftar belanja bahan makanan mereka.Hal tersebut membuktikan bahwa pasar Internasional memiliki peluang besar terhadap pemasaran jamur.

Indonesia

Budidaya jamur konsumsi di menggembirakan.Saat iniIndonesia sudah termasuk sebagai salah satu negara pemasok utama jamur dunia, akibatnya kebutuhan dalam negeri justru terabaikan.Gambaran tersebut 
baru merupakan kebutuhan pasar dalam bentuk jamur segar.Padahal jamur konsumsi tidak hanya dipasarkan dalam keadaan segar, tetapi juga dapat diolah lebih lanjut menjadi produk olahan siap saji seperti keripik jamur, abon jamur, nughet jamur, dan makanan olahan jamur lain.Produk-produk tersebut selain meningkatkan nilai tambah juga merupakan perluasan pemasaran untuk menjaring lebih banyak konsumen.

Salah satu usaha jamur tiram yang ada di Kota Pekanbaru terdapat di Kelurahan Simpang Baru, Kecamatan Tampan dimana terdapat satu orang pengusaha yang membudiyakan usaha jamur tiram dengan luas lahan yang ada yaitu $7 \mathrm{x}$ $9 \mathrm{~m}^{2}$. Petani jamur ini memulai usahanya dari skala rumah tangga, walaupun demikian usaha ini sudah bisa memasarkan produksi jamur tiram putih segar ke pasar-pasar yang ada di Kecamatan Tampan maupun di daerah Kota Pekanbaru sekitarnya.

\section{METODE PENELITIAN \\ Tempat dan Waktu Penelitian}

Penelitian ini dilaksanakan di

Kelurahan Simpang Baru Kecamatan (kuisioner) yang telah disiapkan. Sedangkan data sekunder diperoleh dari instansi pemerintah yang terkait, meliputi keadaan fisik daerah (letak, topografi, dan penduduk).

\section{Analisis Biaya}

Biaya produksi dalam usaha jamur tiram adalah semua biaya yang dikeluarkan oleh petani selama satu kali proses produksi. Biaya produksi

$\mathrm{TC}=\mathrm{TVC}+\mathrm{TFC}$

Dimana:
Tampan Kota Pekanbaru. Lokasi ini diambil secara sengaja karena di lokasi ini terdapat satu orang petani jamur tiram putih yang membudidayakan jamurnya dan belum pernah dianalisis. Data yang diambil adalah data pada tahun 2015 . Waktu penelitian ini dilaksanakan selama dua bulan dari bulan April sampai dengan Juni 2016.

\section{Populasi dan Sampel}

Populasi dalam penelitian ini adalah petani jamur tiram putih di Kelurahan Simpang Baru Kecamatan tampan Kota Pekanbaru hanya ada 1 orang pengusaha sehingga metode yang digunakan adalah metode "Sensus" terhadap pengusaha jamur tiram tersebut yang akan dianalisis per satu kali proses produksi yaitu 4 bulan.

\section{Teknik Pengumpulan Data}

Data yang dikumpulkan adalah data primer dan data sekunder. Dimana data primer adalah data yang diambil secara langsung dengan Petani jamur tiram tersebut dengan melakukan wawancara langsung dan menggunakan daftar pertanyaan

\section{Analisis Data}

terdiri dari biaya tetap dan biaya variabel. Besarnya biaya produksi yang dikeluarkan oleh petani jamur tiram putih dapat dihitung dengan rumus (Soekartawi, 2001) :

$$
\begin{aligned}
\mathrm{TC}= & \text { Total Cost } \\
\text { Produksi }) & (\mathrm{Rp} / \text { Periode } \\
\mathrm{TV}= & \begin{array}{l}
\text { Total Variabel } \\
\text { Produksi })
\end{array}
\end{aligned}
$$


TFC $=$ Total Fixed Cost $(\mathrm{Rp} /$ Periode

Pendapatan

Pendapatan Kotor

Pendapatan kotor usahatani

jamur tiram putih per periode

$\mathrm{TR}=\mathrm{Y}$. Py

Dimana :

TR=Total Penerimaan (Rp/Periode Produksi)

Y=Jumlah Produksi (Rp/Periode

Produksi)

$\mathrm{Py}=$ Harga Produksi $(\mathrm{Rp} / \mathrm{Kg})$

\section{Pendapatan Bersih}

Untuk pendapatan bersih usahatani jamur tiram putih didapat dengan menggunakan rumus (Soekartawi, 2001) :

$\pi=\mathrm{TR}-\mathrm{TC}$

Dimana :

$\pi=$ Pendapatan Bersih $(\mathrm{Rp} /$ Periode Produksi)

$\mathrm{TR}=$ Total Penerimaan $(\mathrm{Rp} /$ Periode Produksi)

$\mathrm{TC}=$ Total $\quad$ Biaya $\quad(\mathrm{Rp} /$ Periode Produksi)

\section{Penyusutan}

Penyusutan Alat yang digunakan dalam usahatani jamur tiram putih dihitung dengan menggunakan metode penyusutan garis lurus (Straight Line Method), (Hernanto,1996) :

$\mathrm{D}=\frac{\mathrm{C}}{\mathrm{UL}}$

Dimana :

$\mathrm{D}=$ Penyusutan

(Rp/PeriodeProduksi)

$\mathrm{C}=$ Harga $(\mathrm{Rp} /$ Periode Produksi $)$

$\mathrm{UL}=$ Umur Ekonomis (Tahun)

Benefit Cost Ratio (BCR)

Untuk meghitung kelayakan usaha jamur tiram putih digunakan analisis Benefit Cost Ratio (BCR) dengan rumus (Soekartawi, 2001) :

$\mathrm{BCR}=\frac{\text { Benefit }}{\text { Cost }}$
Produksi)

produksi didapatkan dengan mengalikan antara produksi dengan harga (Soekartawi, 2001) :

Dimana :

BCR = Benefit Cost Ratio

Benefit=Pendapatan Kotor

(Rp/Periode Produksi)

Cost=Total Biaya Produksi

(Rp/Periode Produksi)

Dengan kriteria.

BCR $>1$ = Berarti usahatani

menguntungkan

BCR $<1=$ Berarti usahatani

tidak menguntungkan

$\mathrm{BCR}=1=$ Berarti usahatani

berada pada titik impas

\section{Break Even Point (BEP)}

Untuk mengetahui titik impas usahatani jamur tiram putih dilakukan dengan menggunakan rumus (Sukiyono, 2004) dengan persamaan sebagai berikut :

\section{BEP dalam unit}

$\operatorname{BEP}(\mathrm{q})=\frac{\mathrm{TFC}}{\mathrm{P}-\mathrm{AVC}}$

Keterangan :

$\mathrm{BEP}=$ Break Event Point

TFC =Total Fixed Cost

(Rp/Periode Produksi)

AVC =Rata-rata Variabel Cost (Rp/Unit)

$\mathrm{P} \quad=(\operatorname{Harga}(\mathrm{Rp} / \mathrm{kg})$

\section{BEP dalam rupiah}

$\operatorname{BEP}(\mathrm{Rp})=\frac{T F C}{1-\frac{A V C}{P}}$

Keterangan :

TFC $=$ Total Biaya Tetap

(Rp/Periode Produksi)

$\mathrm{AVC}=$ Rata-rata biaya variabel

(Rp/unit)

$\mathrm{P}=\operatorname{Harga}(\mathrm{Rp} /$ Unit $)$ 


\section{HASIL PENELITIAN DAN PEMBAHASAN}

\section{Keadaan Umum Daerah Penelitian}

Kelurahan Simpang Baru adalah salah satu kelurahan yang terletak di Kecamatan Tampan Kota Pekanbaru Provinsi Riau. Kelurahan Simpang Baru ini mempunyai luas wilayah sebesar $23.788 \mathrm{~km}^{2}$ yang terbagi menjadi 17 Rukun Warga (RW) dan 91 Rukun Tetangga (RT). Wilayah Kelurahan Simpang Baru terletak dipinggir kota Pekanbaru berkembang maka daerah ini akan mengalami jumlah penduduk yang akan terus meningkat.

\section{Keadaan Penduduk}

Penduduk merupakan unsur yang paling penting dalam hal perubahan sosial dalam suatu masyarakat, baik sebagai objek perubahan maupun sebagai subjek perubahan dalam masyarakat itu sendiri. Jumlah penduduk Kelurahan Simpang Baru Kecamatan Tampan tahun 2016 adalah 47.000 jiwa. Selanjutnya penduduk Kelurahan Simpang Baru dapat pula dilihat berdasarkan kelompok umur, jumlah penduduk Kelurahan Simpang Baru dengan kelompok umur lebih banyak adalah antara 10-14 tahun sebanyak 7.702 jiwa atau $16,35 \%$. Sedangkan untuk kelompok umur yang produktif dimulai dari usia 20-49 tahun yaitu dengan jumlah sebesar 16.615 jiwa atau $35,15 \%$.

Pendidikan merupakan hal yang sangat penting, karena tingkat pendidikan akan mempengaruhi kemampuan untuk berusaha dalam pembangunan. Menurut Soekartawi (2011) tingkat pendidikan akan sangat berpengaruh terhadap cara berpikir dan daya serap seseorang yang langsung berbatasan dengan Kabupaten Kampar Riau. Jumlah penduduk Kelurahan Simpang Baru sebesar 47.000 jiwa yang terdiri dari 21.002 laki-laki dan 25.998 perempuan dengan jumlah KK 6.575. Pada umumnya masyarakat adalah masyarakat heterogen baik ditinjau secara sosial maupun ekonomi. Mata pencaharian penduduk lebih didominasi oleh pedagang, wiraswasta, buruh dan PNS. Sebagai daerah yang berpotensi dan

terhadap teknologi. Tingkat pendidikan yang rendah dapat menurunkan produktifitas tenaga kerja. jumlah penduduk Keluhan Simpang Barudengan tingkat pendidikanlebih banyak adalah tamat SLTP Sederajat sebanyak 12.680 jiwa atau $26,98 \%$.

\section{Usahatani}

Usahatani jamur tiram putih ini milik Bapak Rahmat Irwansyah terletak di Kelurahan Simpang Baru Kecamatan Tampan Kota Pekanbaru.Usaha ini beliau mulai pada tahun 2011 hingga usaha ini berjalan sampai sekarang. Beliau mendirikan kumbung dengan ukuran kumbung 7 x $9 \mathrm{~m}^{2}$ dengan kapasitas kumbung mencapai 10.000 baglog, dalam kumbung terdiri dari 5 tingkat raknya. Namun pada saat ini beliau hanya memproduksi jamur tiram putih sebanyak 5.000 baglog saja.

\section{Budidaya Jamur Tiram Putih}

Tahapan dalam budidaya
jamur tiram putih $\begin{array}{r}\text { meliputi, } \\ \text { pemilihan lokasi, }\end{array}$ pembuatan
kumbung, pembuatan media tanam
(baglog), inokulasi,
penumbuhan jamur


perawatan dan pengendalian hama dan penyakit, panen dan pasca panen. Pemilihan Lokasi, Pembuatan Kumbung, Pembuatan Media Tanam. Langkah-langkah pembuatan baglog dalam usahatani adalah sebagai berikut :

\section{Persiapan Bahan dan Alat}

Persiapan untuk pengumpulan bahan-bahan dan peralatan antara lain bahan-bahaan dan peralatan antara lain bahanbahan yang digunakan: serbuk kayu, dedak/bekatul, tepung jagung, dolomit/kapur dan air. Sedangkan untuk peralatan digunakan plastik PP, cincin paralon, karet gelang, koran, sekop, ember.

\section{Pengayakan}

\section{Pengayakan serbuk kayu perlu dilakukan untuk menghomogenkan ukuran serbuk kayu dan untuk menyaring adanya serpihan-serpihan tajam yang dapat merobek plastik pembungkus media. \\ Percampuran}

Komposisi bahan pembuat baglog yaitu berupa serbuk gergaji kayu 167 karung, dedak 265 kg, dolomit $68 \mathrm{~kg}$, dan tepung jagung 30 $\mathrm{kg}$, pencampuran bahan-bahan, pertama-tama bahan dicampur/diaduk secara merata, setelah itu ditambahkan air bersih, diaduk kembali hingga merata. Jumlah air cukup ditandai dengan cara menggenggam campuran media, tidak terlalu basah (tandanya air merembes), tidak pula kurang (tandanya dapat dilihat bila digenggam kemudian dilepas gumpalan media langsungpecah).

\section{Pengomposan}

Setelah semua bahan dicampur secara merata, proses selanjutnya yaitu pengomposan selama \pm 24 jam (1 hari). Pengomposan dilakukan dengan cara mengumpulkan bahan menjadi satu tumpukan kemudian menutupnya secara rapat dengan menggunakan terpal.

Pembungkusan/ baglog

\begin{tabular}{lr}
\multicolumn{2}{c}{ Setelah pengomposan } \\
langkah selanjutnya & adalah \\
pembungkusan.Media & tanam \\
dimasukkan pada kantong & plastik
\end{tabular}
tebal (polipropilen) berukuran $20 \mathrm{x}$ $30 \mathrm{~cm}$ berkapasitas 1000 gram, kemudian padatkan.Pembungkusan bisa dilakukan menggunakan manual.Pemadatan dilakukan sampai media mencapai ketinggian sekitar $20 \mathrm{~cm}$.Tepat di tengah permukaan media dibuat lubang tanam kira-kira sedalam $10 \mathrm{~cm}$ dengan diameter 2,5 $\mathrm{cm}$ menggunakan kayu atau besi bulat yang steril. Pada ujung plastik yang terbuka di pasang cincin plastik / potongan paralon.

\section{Sterilisasi}

Ditempat usaha budidaya jamur tiram putih ini sterilisasi baglog dilakukan dengan cara memasukkan baglog ke dalam drum dengan suhu 121 derajat $C$ selama 15 menit.Drum dengan kapasitas besar dan dipanaskan di atas kompor gas. Memang, sterilisasi baglog menggunakan drum memakan waktu lebih lama, yaitu sekitar 8 jam, tetapi dianggap lebih menghemat biaya.

\section{Inokulasi}

Inokulasi adalah memasukan bibit kedalam media tanam jamur yang telah disterilisasikan dan didinginkan.Baglog yang telah disterilisasi sebaiknya dipindahkan ke tempat inokulasi dan didiamkan selama 24 jam untuk mengembalikannya ke suhu normal. 
Inkubasi atau pemeraman bertujuan agar bibit yang telah diinokulasi segera ditumbuhi miselium. Untuk menunjang pertumbuhan miselium.

\section{Penumbuhan}

Dalam penumbuhan tubuh buah jamur diperlukan pengaturan suhu dan kelembapan kumbung dengan cara menyiram lantai kumbung dan baglog. Panen bisa dilakukan dengan memiliki ciri pada jamur tersebut yakni tubuh buah tersebut telah memiliki umur maksimal 2-3 hari setelah tubuh buah tumbuh.

\section{Perawatan dan pengendalian hama penyakit}

Proses perawatan dilakukan dengan cara menjaga suhu dan kelembaban ruangan inkubasi. Setiap pagi dan sore sebaiknya disemprotkan air bersih ke dalam ruangan, jangan menyemprot langsung ke media, karena kalau kelebihan air, media akan menjadi busuk.

\section{Panen dan Pasca Panen}

Pemanenan yang benar sangat berpengaruh terhadap kualitas jamur yang dipanen, termasuk di dalamnya adalah kualitas dan daya tahan jamur yang dipanen. Masa produksi dari setiap baglog adalah selama sekitar \pm 70 hari dan dapat dipanen setiap harinya dengan baglog yang tumbuh jamur bergantian. Setiap baglog menghasilkan 600 gram jamur selama masa produksi.Pemanenan dilakukan pada pagi atau sore hari guna untuk mempertahankan kesegaran jamur tersebut.Setelah dilakukan pemanenan kemudian pembersihan, pembersihan dengan membuang kotoran yang menempel pada bagian tubuh buah (bagian tudung atau akar). Jamur
dibersihkan tanpa air, bila
pembersihan menggunakan air,
sebelum dilakukan pemilihan
terlebih dahulu harus ditiriskan Pemasaran

Pada usaha jamur tiram putih milik Bapak Rahmat ini beliau tidak perlu repot untuk memasarkan jamur tiram segarnya, karena beliau mempunyai langganan tetap yang datang ke tempatnya langsung untuk membeli jamur tiram setiap hari yaitu berupa pedagang pengumpul, kemudian pedagang pengumpullah yang memasarkan jamur tiramnya ke pasar-pasar ataupun warung yang ada di daerah panam dan sekitarnya.

\section{Analisis Usahatani Jamur Tiram Putih}

Salah satu tujuan yang dilakukan dalam Usahatani yaitu dengan memperoleh keuntungan atau laba dari usahatani yang dilakukan. Semua tahapan kerja dalam berusahatani tersebut memerlukan biaya yang harus dikeluarkan dan diperhitungkan. Dimana biaya ini di klasifikasikan menjadi dua yaitu biaya tetap (fixed cost) dan biaya tidak tetap (variable cost). Biaya tetap (fixed cost) biaya yang dikeluarkan yang bisa dipakai berulang-ulang dalam proses produksi. Sedangkan biaya tidak tetap (variable cost) biaya yang dikeluarkan yang mempengaruhi besar kecilnya tingkat produksi.

\section{Biaya Proses Produksi}

Biaya Tidak Tetap (Variable cost)

Biaya tidak tetap (variable cost) biaya yang dikeluarkan yang mempengaruhi besar kecilnya tingkat produksi.Biaya ini meliputi biaya pembuatan baglog, pembelian plastik 
packing dan tenaga kerja.Untuk penggunaan biaya tidak tetap (variable cost) dalam usahatani

jamur tiram putih selama satu periode produksi dapat dilihat pada tabel 5.

Tabel 5. Distribusi Biaya tidak tetap (variable cost) Usahatani Jamur Tiram Putih

\begin{tabular}{|c|l|c|c|c|}
\hline No & \multicolumn{1}{|c|}{ Uraian } & Unit & $\begin{array}{c}\text { Harga satuan } \\
(\mathrm{Rp})\end{array}$ & Nilai (Rp) \\
\hline 1. & Pembuatan Baglog & 5.000 & 1114.5 & 5.572 .000 \\
\hline 2. & Plastik Packing & $5(\mathrm{~kg})$ & 35.000 & 175.000 \\
\hline 3. & Tenaga Kerja & $105(\mathrm{HKP})$ & 80.000 & 8.400 .000 \\
\hline \multicolumn{4}{|c|}{ Jumlah } & $\mathbf{1 4 . 1 4 7 . 0 0 0}$ \\
\hline
\end{tabular}

\section{Pembuatan Baglog}

Baglog merupakan media tumbuh jamur tiram putih yang terbuat dari campuran serbuk gergaji, dedak, dolomit, tepung jagung yang di proses sehingga menjadi media tempat tumbuhnya jamur tiram putih. Biaya tidak tetap (variable cost) yang dikeluarkan untuk pembuatan baglog dapat dilihat pada tabel 6.

Tabel 6. Arus biaya tidak tetap (variable cost) untuk pembuatan 5.000 baglog

\begin{tabular}{|c|l|c|c|c|c|}
\hline No & \multicolumn{1}{|c|}{ Komponen } & Kebutuhan & Satuan & Harga & Nilai \\
\hline 1. & Serbuk gergaji & 167 & Karung & 3500 & 584.500 \\
\hline 2. & Dedak & 265 & $\mathrm{Kg}$ & 2500 & 662.500 \\
\hline 3. & Dolomit & 68 & $\mathrm{Kg}$ & 500 & 34.000 \\
\hline 4. & Tepung jagung & 30 & $\mathrm{Kg}$ & 6000 & 180.000 \\
\hline 5. & Bibit & 125 & $\mathrm{Botol}$ & 10000 & 1.250 .000 \\
\hline 6. & Plastik PP & 20 & $\mathrm{Kg}$ & 35000 & 700.000 \\
\hline 7. & Karet gelang & 6 & $\mathrm{Kg}$ & 45000 & 270.000 \\
\hline 8. & Kertas Koran & 5 & $\mathrm{Kg}$ & 2000 & 10.000 \\
\hline 9. & Alkohol & 3 & $\mathrm{~L}$ & 25000 & 75.000 \\
\hline 10. & Gas (3kg) & 17 & $\mathrm{Tabung}$ & 18000 & 306.000 \\
\hline 11. & Tenaga kerja (borongan) & 105 & $\mathrm{Baglog}$ & 300 & 1.500 .000 \\
\hline 12. & Tenaga kerja & $\mathrm{HKP}$ & 80.000 & 8.400 .000 \\
\hline 13. & Plastik packing & & $\mathrm{Kg}$ & 35.000 & 175.000 \\
\hline \multicolumn{5}{|c|}{ Jumlah } \\
\hline
\end{tabular}

jumlah biaya variabel untuk pembuatan 5.000 baglog sebesar Rp. 5.572.000,- dimana biaya variabel adalah biaya tenaga kerja yang mencapai nilai sebesar Rp. 1.500.000,-. Tenaga kerja untuk pembuatan baglog ini dihitung secara borongan, mulai dari pengadukan bahan baku hingga baglog tersusun dirak tempat inkubasi atau penumbuhan misselium. Setiap baglog yang dihasilkan diberi upah sebesar Rp. 300,-Sehingga untuk

Tabel 7. Biaya penyusutan kumbung dan peralatan dalam satu periode usaha skala 5.00 baglog mendapatkan 5.000 baglog Bapak Rahmat harus mengeluarkan biaya tenaga kerja sebesar Rp. 1.500.000,-, Biaya Tetap (Fixed Cost)

Analisis biaya penyusutan kumbung dan peralatan pertanian menggunakan metode penyusutan garis lurus (straight line method), dimana metode ini menghitung besarnya penyusutan tiap-tiap asset selalu sama di tiap periode selama umur ekonomisnya. 


\begin{tabular}{|c|l|c|c|c|c|c|c|}
\hline No & Uraian & Jumlah & $\begin{array}{c}\text { Umur } \\
\text { ekonomis }\end{array}$ & $\begin{array}{c}\text { Harga } \\
\text { satuan (Rp) }\end{array}$ & Nilai (Rp) & $\begin{array}{c}\text { Penyusutan/tahun } \\
\text { (Rp) }\end{array}$ & $\begin{array}{c}\text { Penyusutan/ } \\
\text { periode } \\
\text { (Rp) }\end{array}$ \\
\hline 1. & Kumbung & 1 & 5 & 10.000 .000 & 10.000 .000 & 2.000 .000 & 666.000 \\
\hline 2. & Pompa air & 1 & 5 & 150.000 & 150.000 & 30.000 & 10.000 \\
\hline 3. & Slang 20 m & 1 & 3 & 180.000 & 180.000 & 60.000 & 20.000 \\
\hline 4. & Timbangan & 1 & 5 & 150.000 & 150.000 & 30.000 & 10.000 \\
\hline 5. & Keranjang & 3 & 4 & 25.000 & 75.000 & 18.750 & 6.250 \\
\hline 6. & Pisau & 3 & 1 & 20.000 & 60.000 & 60.000 & 20.000 \\
\hline 7. & Gunting & 1 & 1 & 15.000 & 15.000 & 15.000 & 5.000 \\
\hline 8. & Thermometer & 1 & 3 & 200.000 & 200.000 & 66.666 & 22.222 \\
\hline 9. & Angkong & 1 & 3 & 200.000 & 200.000 & 66.666 & 22.222 \\
\hline 10. & Karung & 167 & 1 & 1.000 & 167.000 & 167.000 & 55.666 \\
\hline 11. & Drum & 4 & 3 & 100.000 & 400.000 & 133.333 & 44.444 \\
\hline 12. & Sekop & 1 & 2 & 50.000 & 50.000 & 25.000 & 8.333 \\
\hline 13. & Alat press & 1 & 5 & 200.000 & 200.000 & 40.000 & 13.333 \\
\hline 14. & Cincin & 5.000 & 3 & 70 & 350.000 & 116.666 & 38.888 \\
\hline 15. & Tabung & 4 & 5 & 100.000 & 400.000 & 80.000 & 26.666 \\
\hline 16. & Selang gas & 4 & 3 & 200.000 & 800.000 & 266.666 & 88.888 \\
\hline
\end{tabular}

biaya yang dikeluarkan untuk biaya penyusutan dan peralatan secara keseluruhan sebesar $\mathrm{Rp}$. 1.057.912dari total biaya tetap. Bila dilihat dari masing-masing komponen biaya penyusutan per proses produksi maka, alokasi biaya terbesar adalah biaya penyusutan kumbung yang mencapai Rp. 666.000 dan biaya penyusutan terendah adalah gunting sebesar Rp.5.000.Total biaya tetap untuk usahatani jamur tiram putih di Kelurahan Simpang Baru Kecamatan Tampan Kota Pekanbaru dapat dilihat pada tabel 8 .

Tabel 8. Distribusi biaya tetap (Fixed cost) usahatani jamur tiram putih

\begin{tabular}{|c|c|c|}
\hline Komponen Biaya Tetap & Nilai (Rp) & Persentase (\%) \\
\hline -Sewa lahan & 2.000 .000 & 57.84 \\
\hline -Penyusutan Peralatan & 1.057 .912 & 30.59 \\
\hline -Listrik & 400.000 & 11.57 \\
\hline Total & 3.457.912 & 100 \\
\hline
\end{tabular}

\section{Produksi dan Pendapatan}

Dalam satu kali produksi usahatani jamur tiram putih di Kelurahan Simpang Baru Kecamatan Tampan Kota Pekanbarumampu memproduksi $1200 \mathrm{Kg}$, hasil tersebut didapat dari 5.000 baglog, dimana produksi setiap baglognya \pm 600 gr. Pendapatan kotor merupakan perkalian produksi dengan harga penjualan dalam satuan unit sedangkan pendapatan bersih adalah selisih antara pendapatan kotor dengan total biaya usahatani. Pendapatan yang diperoleh dalam usahatani jamur tiram putih per satu kali produksi (4bulan) di Kelurahan Simpang Baru Kecamatan Tampan Kota Pekanbaru dapat dilihat dalam Tabel 9.

Tabel 9. Pendapatan usahatani jamur tiram putih

\begin{tabular}{|c|l|c|c|}
\hline \multicolumn{2}{|c|}{ Pendapatan } & & Nilai (Rp) \\
\hline 1. & Produksi (Kg) & 1200 & \\
\hline 2. & Harga Jual (Kg) & & 30.000 \\
\hline 3. & Total Biaya Produksi (Rp) & & 17.604 .912 \\
\hline 4. & Pendapatan Kotor (Rp) & & 36.000 .000 \\
\hline
\end{tabular}




\begin{tabular}{c|c|c|}
\hline 5. & Pendapatan Bersih (Rp) & 18.395 .088 \\
\hline Analisis Benefit Cost Ratio (BCR) & biaya (TC) dalam satu kali periode \\
Kelayakan suatu usaha dapat & $\begin{array}{l}\text { produksi usahatani. Nilai BCR yang } \\
\text { diperoleh dalam satu kali produksi (4 }\end{array}$ \\
$\begin{array}{c}\text { dilihat melalui BCR.BCR dapat } \\
\text { diketahui dari hasil perbandingan }\end{array}$ & bulan) dapat diketahui dengan cara:
\end{tabular}

antara pendapatan kotor dengan total

$\begin{array}{ll}\text { BCR } & =\frac{\text { Benefit }}{\text { cost }} \\ \text { Benefit } & =\text { Rp. } 36.000 .000 \\ \text { Cost } & =\text { Rp } 17.604 .912 \\ \text { BCR } & =\frac{36.000 .000}{17.604 .912} \\ \text { BCR } & =2.04\end{array}$

Dapat diketahui bahwa nilai BCR untuk usahatani jamur tiram putih di Kelurahan Simpang Baru Kecamatan Tampan Kota Pekanbaru dalam satu kali proses produksi (4 bulan) sebesar Rp. 2.04ini berarti bahwa setiap pengeluaran Rp. 1 maka akan memberikan pendapatan bersih sebesar Rp. 1.04. dari nilai BCR yang telah diperoleh dengan nilai besar dari 1 maka dapat dikatakan bahwa usahatani jamur tiram putih di Kelurahan Simpang Baru Kecamatan Tampan Kota Pekanbaru milik Bapak Rahmat menguntungkan dan layak untuk diteruskan.

$$
\begin{array}{ll}
\operatorname{BEP}(\mathrm{q}) & =\frac{T F C}{P-A V C} \\
\mathrm{TFC} & =3.457 .912 \\
\text { Harga }(\mathrm{P}) & =\mathrm{Rp} .30 .000 \\
\text { Biaya/Kg }(\mathrm{AVC}) & =\mathrm{Rp} .11 .789 \\
\operatorname{BEP}(\mathrm{q}) & =\frac{3.457 .912}{30.000-11.789} \\
\operatorname{BEP}(\mathrm{q}) & =\frac{3.457 .912}{18.211} \\
\operatorname{BEP}(\mathrm{q}) & =189.88 \mathrm{Kg}
\end{array}
$$

\section{Analisis Break Even Point (BEP)}

Break even point merupakan titik atau keadaan dimana suatu usaha tidak memperoleh keuntungan dan tidak menderita kerugian. BEP tersebut dapat dicapai jika penerimaannya sama besar dengan total biaya yang dikeluarkan $(\mathrm{TR}=\mathrm{TC})$. Dengan kata lain BEP terjadi apabila usaha atau kegiatan didalam operasinya menggunakan biaya tetap dan volume penjualannya hanya cukup menutupi biaya tetap dan biaya variable. Untuk mengetahui nilai break even point dalam unit dapat dihitung dengan cara :

Sedangkan untuk mengetahui nilai Break even point dalam rupiah dapat dihitung dengan cara :

$$
\mathrm{BEP}(\mathrm{Rp}) \quad=\frac{T F C}{1-\frac{A V C}{P}}
$$




$$
\begin{array}{ll}
\operatorname{BEP}(\mathrm{Rp}) & =\frac{3.457 .912}{1-\frac{11.789}{30.000}} \\
\mathrm{BEP}(\mathrm{Rp}) & =\frac{3.457 .912}{1-0.39} \\
\mathrm{BEP}(\mathrm{Rp}) & =\frac{3.457 .912}{0.61} \\
\mathrm{BEP}(\mathrm{Rp}) & =\mathrm{Rp} .5 .668 .708
\end{array}
$$

Dalam usahatani jamur tiram putih selama satu kali produksi dengan skala 5.000 baglog yang diusahakan di Kelurahan Simpang Baru Kecamatan Tampan Kota Pekanbaru diketahui Break Even Point (BEP) usahatani jamur tiram putih tercapai pada penjualan dengan nilai Rp. 5.668.708. Sedangkan

\section{KESIMPULAN DAN SARAN Kesimpulan}

Hasil dari penelitian yang telah dilaksanakan di Kelurahan Simpang Baru Kecamatan Tampan Kota Pekanbaru maka dapat disimpulkan sebagai berikut :

1. Total biaya yang dialokasikan untuk 5.000 baglog selama satu periode produksi (4 bulan) adalah Rp. 17.604.912 terdiri dari biaya tidak tetap (variable cost)adalah sebesar Rp. 14.147.000 dan biaya tetap (fixed cost) adalah sebesar Rp.3.457.912. Produksi yang dihasilkan sebanyak $1200 \mathrm{Kg}$, harga yang dijual oleh petani senilai Rp. 30.000. Pendapatan kotor yang diterima adalah sebesar Rp. 36.000.000 dan pendapatan bersih sebesar Rp.18.395.088

2. Nilai kelayakan usahatani jamur tiram putih di Kelurahan Simpang Baru Kecamatan
Break Even Pointdalam unit $189.88 \mathrm{Kg}$.Itu artinya dengan menerima uang sebesar Rp. 5.668.708dari penjualan jamur tiram putih atau penjualan jamur telah mencapai $189.88 \mathrm{Kg}$, maka petani dalam keadaan tidak rugi atau tidak untung.

Tampan Kota Pekanbaru, Benefit cost ratio (BCR) sebesar 2.04 .

3. Break even point (BEP) dalam unit adalah sebesar $189.88 \mathrm{Kg}$ sedangkan dalam rupiah adalah sebesar Rp. 5.668.708

\section{Saran}

1. Diharapkan bagi petani hendaknya lebih meluaskan lagipemasaran jamur tiram segarnya ke supermarket yang ada dipekanbaru dan mengemasnya dengan menggunakan brand sendiri agar dapat menarik para konsumen.

2. Jika petani lebih meluaskan lagi pemasarannya maka volume produksi dari 5.000 baglog ini akan bisa di tingkatkan dari sebelumnya, karna jika produksinya meningkat maka akan menerima hasil yang tinggi dan keuntungan yang besar pula bagi petani.

\section{DAFTAR PUSTAKA}


Agustina, W. 2014.Karya Tulis Ilmiah, Budidaya Jamur Tiram, Yogyakarta.

Chazali, S dan Pratiwi, P.S. 2009.Usaha Jamur Tiram Skala Rumah Tangga,Penebar Swadaya, Jakarta.

Direktorat Jendral Hortihultura. 2010. Perkembangan Pendapatan Domestik Bruto Holtihultura, Jakarta.

Gadang, D. 2011. Analisis Peranan Sektor Pertanian Terhadap Perekonomian.Universitas Diponegoro,

Semarang.

Hedritomo, H. I,.Tjokrokusumo, dan I. Djajanegara. 2008. Pengaruh Mutasi Radiasi Sinar Gmm (Co60) terhadap Produksi Jamur Tiram Putih( Pleurotus ostreatus). Jurnal Biotika 6 (1): 8-14.

Hernanto. F. 1996. Ilmu Usahatani.Penebar Swadaya, Jakarta

Irhananto, Y. 2014. Pertumbuhan dan Produktifitas Jamur

Sukiyono. 2004. Metode Penelitian Bisnis, Alfaberta, Bandung.

Wardani, C. 2014. Kadar Protein Jamur Tiram Putih
Tiram Putih. UMS, Surakarta.

Kasymir, E. 2011.Efesiensi Produksi dan Pendapatan Usahatani. Universtitas Lampung, Bandar Lampung.

Mubyarto. 1991. Pengantar Ekonomi Pertanian. LP3ES. Jakarta.

Rahim, A dan Hastuti.2008. Ekonomika Pertanian. Penebar Swadaya, Yogyakarta.

Riyanto, B dan Munawir. 2001. Analisa Laporan Finansial. Penerbit Liberti, Yogyakarta.

Shifiyah, A dan Badami, K. 2012.Pertumbuhan dan Produksi Jamur Tiram Putih. UTM, Surakarta.

Soekartawi. 1995. Prinsip-Prinsip Dasar Ekonomi Pertanian Teori dan Aplikasi. PT raja Grafindo Persada, Jakarta. 2001.Agribisnis Teori dan Aplikasinya, Rajawali press, Jakarta. 2002 Analisis Usahatani, UI

Press, Jakarta.

Sukirno, Sadono, 2002. Pengantar Teori Ekonomi Mikro, Edisi 3, Penerbit PT. Raja Grafindo Persada, Jakarta. (Pleorotus ostreatus) Pada Media Campuran. Surakarta 